\title{
$N$-(Di)icosyl-substituted benzo[a]phenoxazinium chlorides: synthesis and evaluation as near-infrared membrane probes
}

\author{
Sarala Naik, ${ }^{[a]}$ Carla M. A. Alves, ${ }^{[a]}$ Paulo J. G. Coutinho, ${ }^{[b]}$ and M. Sameiro T. Gonçalves ${ }^{[a]}$ \\ [a] Centre of Chemistry, University of Minho, 4710-057 Braga, Portugal \\ Fax: +351253604382 \\ E-mail: msameiro@quimica.uminho.pt \\ [b] Centre of Physics, University of Minho, 4710-057 Braga, Portugal
}

Keywords: Benzo[a]phenoxazinium dyes / Membrane probes / Near-infrared labels / Nile Blue / Cationic dyes

Five benzo $[a]$ phenoxazinium chlorides containing alkyl chains with twenty carbon atoms on 5- or 9positions of the tetracyclic ring were efficiently synthesised and characterised by UV/Vis/NIR spectroscopy. The absorption and emission maxima in ethanol lie in the range 627-641 nm and 645-676 nm, respectively, with quantum yields varying from 0.14 to 0.38 . Preliminary photophysical studies with these fluorochromophores in zwitterionic (2,3- bis(palmitoyl- oxy)propyl-2-(trimethylammonio)ethyl phosphate, DPPC) and cationic ( $N, N$-dimethyl- $N$-octadecyloctadecan-1-aminium bromide, DODAB) vesicles were carried out. The results showed that the new benzo[ $[a]$ phenoxazinium derivatives are able to detect the gel to liquid-crystalline lipid phase transition through variations, either in the H-aggregation extent or in an acidbase equilibrium.

\section{Introduction}

Cellular membranes, selective barriers separating inside and outside cellular volumes, are crucial to the interactions with the cell exterior by enabling the transfer of many important compounds for cell metabolism and for chemical and electrical signaling. ${ }^{[1-3]}$ In all biomembranes, the lipid bilayer constitutes the backbone, in which various proteins and glycan-containing membrane anchors are embedded.

The understanding of the biological functions of cell membranes is directly connected with their fundamental physicochemical properties. Several parameters, such as membrane electrostatics, phase state, hydration, and dynamics of the constituting molecules, establish the membrane structure and control the binding and transport of molecular and ionic species. Furthermore, they determine the correct insertion, proper folding, and function of membrane proteins. ${ }^{[4]}$ 
Fluorescent probing is one of the most suitable methods for the monitoring of these parameters in situ and the environment-sensitive fluorophores are of extreme importance. These compounds provide information on the properties of the molecular environment through changes in their photophysical characteristics. ${ }^{[5-10]}$

The variety of fluorescent markers used in studies of the biophysical properties of lipid membranes, includes 9-(dicyanovinyl) julolidine (DCVJ), 7-nitrobenz-2-oxa-1,3-diazol-4- yl (NBD), Prodan, 7(dialkylamino)-coumarin, styryl, 3-hydroxychromone (3HC) and their derivatives, as well as Nile Red and Nile Blue; the last two are oxazine dyes. ${ }^{[1-20,8,4]}$

The synthesis of novel fluorochromophores based on the oxazine core with substituents, which allow for their interaction with a variety of biological molecules, is important for labelling purposes. ${ }^{[21]}$ Most biological macromolecules and structures have hydrophobic and hydrophilic zones, hence the presence of a long alkyl chain in the fluorescence label allows it to easily bind to the hydrophobic parts of biomolecules or biomembranes, enabling the fluorophore to probe its environment. ${ }^{[22]}$

When these types of probes are incorporated in biomembranes, their oxazine core can report on the local changes of the membrane properties, namely micropolarity, the hydration level, charge and microviscosity. These properties are important to understand the structure, dynamics and function of the biological membrane, as previously mentioned. The cationic nature of benzophenoxazinium fluorophores is expected to allow them to probe the charge density of the biomembrane.

Considering these facts, and as part of our current research interests in the synthesis and characterisation of fluorescence probes, ${ }^{[23-30]}$ this work describes the synthesis of five benzo[ $\left.a\right]$ phenoxazinium chlorides with different combinations of substituents at 5-, 9- and 10-positions of the polycyclic aromatic ring, as well as the study of their photophysical behaviour in homogeneous media and in zwitterionic/cationic vesicles, regarding the changes in the substitution positions.

\section{Results and Discussion}

\section{Synthesis}

Benzo[a]phenoxazinium chlorides 1a-e were synthesised by the condensation of 5-(alkylamino)-2nitrosophenol hydrochlorides 2a-e with $N$-alkylnaphthalen-1-amines 3a or $\mathbf{3 b}$ in acid media (Scheme 1). The required nitrosophenol 2a-e was obtained by nitrosation of the corresponding 3-alkylaminophenol derivative with sodium nitrite and hydrochloric acid, in water or a mixture of ethanol-water as the solvent. ${ }^{[23-31]}$ The 3(icosylamino)phenol and 3-(diicosylamino)phenol, precursors of compounds $\mathbf{2 d}$ and $\mathbf{2 e}$, as well as $N$ icosylnaphthalen-1-amine 3a or $N$-propylnaphthalen-1-amine $\mathbf{3 b}^{[28,29]}$ were obtained by alkylation of 3aminophenol and naphthalen-1-amine with 1-bromoicosane or 1-bromopropane (in the case of compound $\mathbf{3 b}$ ), in ethanol, in moderate to good yields. Precursors of nitrosophenols 2a-c were commercial reagents. 
Condensation of 5-ethylamino-4-methyl-2-nitrosophenol hydrochloride 2a, 5-diethylamino-2nitrosophenol hydrochloride $\mathbf{2 b}$ and 5-dimethylamino-2-nitrosophenol hydrochloride $\mathbf{2 c}$, with $N$ icosylnaphthalen-1-amine 3a in the presence of hydrochloric acid, gave the benzo[ $a]$ phenoxazinium chlorides 1a-c. Starting from 5-(icosylamino)-2-nitrosophenol hydrochloride 2d and 5-(diicosylamino)-2nitrosophenol hydrochloride $\mathbf{2 e}$, and using $N$-propylnaphthalen-1-amine $\mathbf{3 b}$, compounds $\mathbf{1 d}$ and $\mathbf{1 e}$ were obtained, respectively. After purification by column chromatography on silica gel, cationic dyes 1a-e were isolated as blue solid materials in good to excellent yields (Table 1), and were fully characterised by high resolution mass spectrometry, IR and NMR $\left({ }^{1} \mathrm{H}\right.$ and $\left.{ }^{13} \mathrm{C}\right)$ spectroscopy.

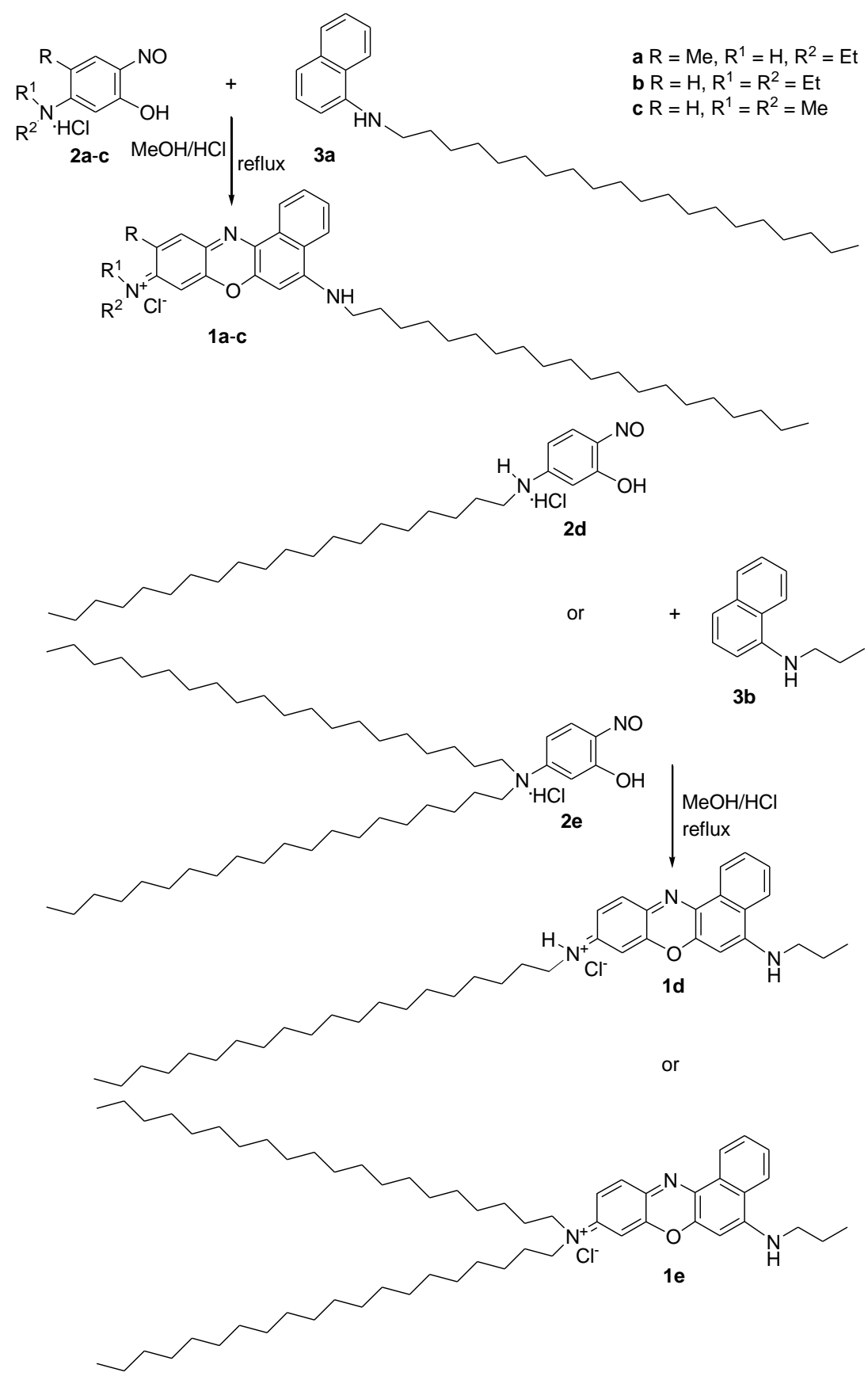

Scheme 1. Synthesis of benzo[a]phenoxazinium chlorides 1a-e. 
The IR spectra of these benzo[a]phenoxazinium dyes showed the expected bands due to stretching vibrations of the amine function (3450-3402 $\mathrm{cm}^{-1}$ ), the C-H linkage of the methyl and methylenic groups (2956-2850 $\left.\mathrm{cm}^{-1}\right)$, the C-C linkage of the aliphatic chains $\left(1186-817 \mathrm{~cm}^{-1}\right)$, as well as a strong band of the $\mathrm{C}=\mathrm{N}$ bond $\left(1657-1590 \mathrm{~cm}^{-1}\right)$ as a result of the oxazine ring.

Table 1. Synthesis and UV/Vis/NIR data for compounds 1a-e in ethanol.

\begin{tabular}{llllll}
\hline Compound & $\begin{array}{l}\text { Yield } \\
(\%)\end{array}$ & $\begin{array}{c}\varepsilon\left(\mathrm{M}^{-}\right. \\
\left.{ }^{1} \mathrm{~cm}^{-1}\right)\end{array}$ & $\begin{array}{l}\lambda_{\text {abs }} \\
(\mathrm{nm})\end{array}$ & $\begin{array}{l}\lambda_{\mathrm{em}} \\
(\mathrm{nm})\end{array}$ & $\Phi_{\mathrm{F}}$ \\
\hline 1a & 73 & 89888 & 627 & 645 & 0.38 \\
1b & 68 & 56930 & 637 & 671 & 0.23 \\
1c & 85 & 63961 & 631 & 670 & 0.14 \\
1d & 37 & 27413 & 627 & 647 & 0.36 \\
1e & 70 & 48553 & 641 & 676 & 0.14 \\
\hline
\end{tabular}

The ${ }^{1} \mathrm{H}$ NMR spectra showed signals from the methyl groups of the aliphatic chains in the form of triplets or a broad singlet (1e) $(\delta 0.83-1.09 \mathrm{ppm})$; the methyl group directly linked to the aromatic ring as a singlet $(\delta$ $2.40 \mathrm{ppm} ; 1 \mathbf{1 a})$. In compound 1c, with dimethylamine at 9-position of the benzo[ $a]$ phenoxazinium ring, the methyl protons occurred as singlets $(\delta 3.24 \mathrm{ppm})$. The methyl protons of the ethyl groups $\left(\mathrm{R}_{1}\right.$ and/or $\left.\mathrm{R}_{2}\right)$ appeared as a multiplet (1a) or a triplet (1b) $(\delta 1.19-1.40 \mathrm{ppm})$. For all compounds, the methylenic groups closed to the nitrogen atoms $\left(\mathrm{NHCH}_{2} \mathrm{CH}_{2}\right)$ in 5- or 9-positions of heterocycles appeared as broad singlets or a multiplet (1c) $\left(\delta\right.$ 1.71-1.95 ppm), and the protons directly linked to the nitrogen atoms $\left(\mathrm{NHCH}_{2} \mathrm{CH}_{2}\right)$ appeared as broad singlets or a multiplet $(\mathbf{1 c})(\delta 3.27-3.81 \mathrm{ppm})$. Spectra also showed the expected aromatic protons, in particular, H-10 as doublets or a broad singlet (1d) $(\delta 6.92-7.11 \mathrm{ppm}), \mathrm{H}-8$ as singlets $(\mathbf{1 a}$ and 1b), a meta doublet $(\mathbf{1 c})(\mathrm{J} 2.7 \mathrm{~Hz})$ or broad singlets (1d and 1e) $(\delta 6.10-6.48 \mathrm{ppm})$, and H-11, which appeared as a singlet (1a), a multiplet $(\mathbf{1 e})$ or as doublets $(\delta 7.37-7.90 \mathrm{ppm})$.

The ${ }^{13} \mathrm{C}$ NMR spectra showed the signals corresponding to the aliphatic $N$-substituents in the heterocycle, namely the methyl groups ( $\delta 11.55-14.05 \mathrm{ppm}$ ), and the methyl group directly attached to the benzene ring (1a) $(\delta 18.29 \mathrm{ppm})$. For compound 1c with dimethylamine at 9-position of the benzo[ $a]$ phenoxazinium ring, the methyl carbons appeared at $\delta 41.10 \mathrm{ppm}$. For all compounds, carbons of methylenic groups closed to the nitrogen atom $\left(\mathrm{NHCH}_{2} \mathrm{CH}_{2}\right)$ in 5- and 9-positions of heterocycles appeared between 21.98 and $30.77 \mathrm{ppm}$ and the carbon atoms directly linked to nitrogen $\left(\mathrm{NHCH}_{2} \mathrm{CH}_{2}\right)$ occurred between 38.67 and $52.02 \mathrm{ppm}$. Spectra also showed the expected aromatic signals such as, C-6 ( $\delta$ 92.29-93.44 ppm), C-8 ( $\delta$ 93.08-95.81 ppm) and C-11 ( $\delta 131.01-132.39 \mathrm{ppm})$. 


\section{Photophysical studies}

Electronic absorption and emission spectra of $10^{-6} \mathrm{M}$ solutions in degassed absolute ethanol were measured for all the synthesised benzo[ $[a]$ phenoxazinium chlorides 1a-e. It was observed that the absorption maxima $\left(\lambda_{\text {abs }}\right)$ for 1a-e lie in the range of 627-641 nm, with molar absorptivities $(\varepsilon)$ between 27413 and $89888 \mathrm{M}^{-1} \mathrm{~cm}^{-}$ ${ }^{1}$ ). The emission maxima $\left(\lambda_{\text {em }}\right)$ were found to be in the range of $645-676 \mathrm{~nm}$, by exciting at $570 \mathrm{~nm}$. It can also be seen that 1a, with one $\mathrm{C}_{20}$ alkyl chain at 5-position and one methyl group at 10-position, has the same absorption and emission maxima as $\mathbf{1 d}$, which has one $\mathrm{C}_{20}$ alkyl chain at 9-position but without the methyl group at 10-position. The fluorescence quantum yields measured with Oxazine 1 as a standard (fluorescence quantum yield, $\Phi_{\mathrm{F}}=0.11$ in ethanol $)^{[32]}$ for $\mathbf{1 a}$ and $\mathbf{1 d}$ are similar $(0.38$ and 0.36$)$. Hence it can be formulated that similar substitutions at 5- and 9-positions reveal similar fluorescence parameters, irrespective of the substitution at 10-position.

Similarly, dyes 1b, 1c and 1e have comparable values for absorption maxima, emission maxima and quantum yields. In contrast to 1a and 1d, which are monoalkyl substituted at 9-position, derivatives with an dialkyl substitution at 9-position showed a batochromic shift in absorption and emission maxima, the latter being superior (about $35 \mathrm{~nm}$ ), but presenting lower fluorescence quantum yields $(0.14$ or 0.23 ). The above results suggested that mono-substitution at 9-position displayed better fluorescence quantum yields than the di-substitution, irrespective of the chain length and the substitution at 10-position.

As an initial photophysical study in biological model systems, compounds $\mathbf{1 a}, \mathbf{1 d}$ and $\mathbf{1 e}$ were incorporated in zwitterionic (DPPC) and cationic (DODAB) vesicles (Figure 1). It was observed that, with the exception of compound 1d in DPPC, these compounds are able to detect the gel to liquid-crystalline lipid phase transition by simple absorption measurements as well as by steady state fluorescence emission (Figures 2-4).

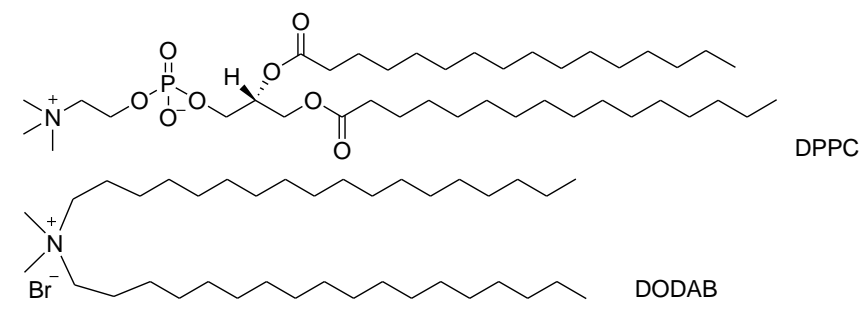

Figure 1. Structures of DPPC and DODAB.

It was previously shown that, depending on the physicochemical environment, 5,9-disubstituted benzo[ $[a]$ phenoxazinium dyes can form $\mathrm{H}$-aggregates (absorption at $\sim 50 \mathrm{~nm}$ to the blue) and are involved in acid base equilibria (absorption at $\sim 100 \mathrm{~nm}$ to the blue) ${ }^{[23-30]}$ Recently, we have also found that the main site of acid-base equilibria is the amine at 5-position. ${ }^{[29]}$ An acid-base equilibrium was not observed in aqueous 
solutions, probably due to the fact that the basic neutral form was H-bonded and showed a similar photophysical behaviour to the positive acid form.

In the DPPC vesicles, all the compounds seem to be well hydrated near the beginning of the membrane interface as the basic form is not observed. It can also be seen that the icosylamino substituent at the 9position (compounds 1d and 1e) prevents the formation of H-aggregates, which are non-fluorescent. This aggregation process happens for compound 1a (Figure 2) when DPPC is present in the gel phase, but is lost when the DPPC membrane undergoes its phase transition. The temperature increases should reduce the fluorescence intensity as the rate of the competing non-radiative internal conversion process increases. However, an increase in the fluorescence intensity is observed for compound 1a, which is explained by the absence of non-fluorescent $\mathrm{H}$-aggregates in the liquid crystalline membrane phase. The 9-dialkylated-amino derivative 1e (Figure 4) detects the lipid phase transition with a shift to the blue in both absorption and emission maxima. Considering that the hydration and fluidity of the interface increase in the liquidcrystalline phase, ${ }^{[18]}$ this can be interpreted by the relocation of the compound towards the hydrophobic interior of the membrane, as it has been previously shown ${ }^{[23]}$ that for these types of compounds a decrease in polarity results in a blue spectral shift. The presence of the double chain is important for this relocalization process since it is not observed for the single-chain equivalent derivative (compound $\mathbf{1 d}$ ).

The behaviour of the benzo[ $[a]$ phenoxazinum chlorides 1a-e in positive DODAB vesicles is completely different. In this case, an acid-base equilibrium is clearly observed for compounds $\mathbf{1 d}$ and $\mathbf{1 e}$ (Figures 3 and 4), which can be interpreted by their deeper position in the interior of the membrane to get way of the positive charge of DODAB molecules. Although the basic form is dominant, the fluorescence spectra is typical of the acid form, since its fluorescence quantum yield is much higher. ${ }^{[23,29]}$ Upon the gel to liquidcrystalline phase transition, the proportion of the basic form nearly goes to unity and the fluorescence spectrum is now dominated by a low intensity band that corresponds to the basic form. This effect is greater for the compound with a single side-chain at the 9-position of the benzo[ $a]$ phenoxazinum $1 \mathbf{d}$. The absence of an acid-base equilibrium in compound 1a can easily be explained by the fact that, upon membrane insertion, the 5-amino position will be buried within the aliphatic chain, making deprotonation impossible. Furthermore, H-aggregation is observed for this compound, decreasing with the membrane phase transition, as observed for DPPC. 

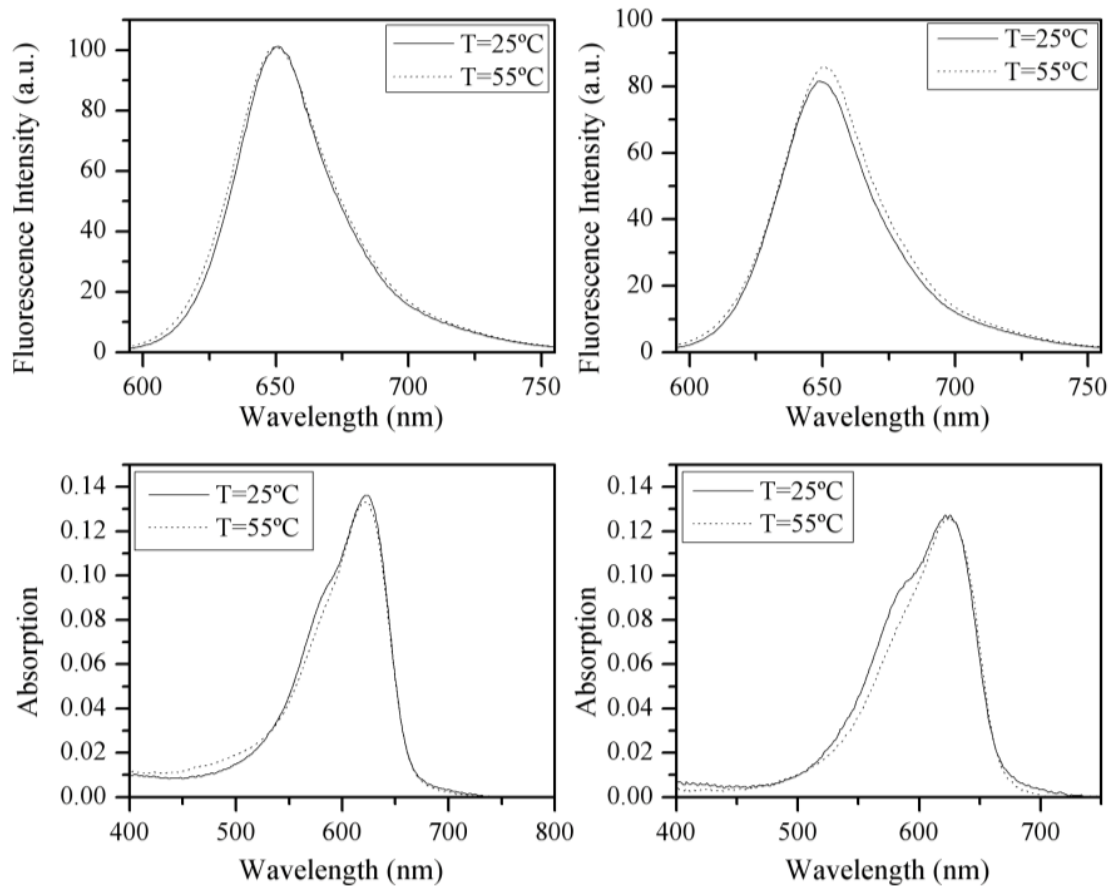

Figure 2. Absorption and fluorescence spectra of compound 1a in DODAB (left) and DPPC (right) vesicles below $\left(T=25^{\circ} \mathrm{C}\right)$ and above $\left(T=55^{\circ} \mathrm{C}\right)$ the gel to liquid-crystalline lipid phase transition.
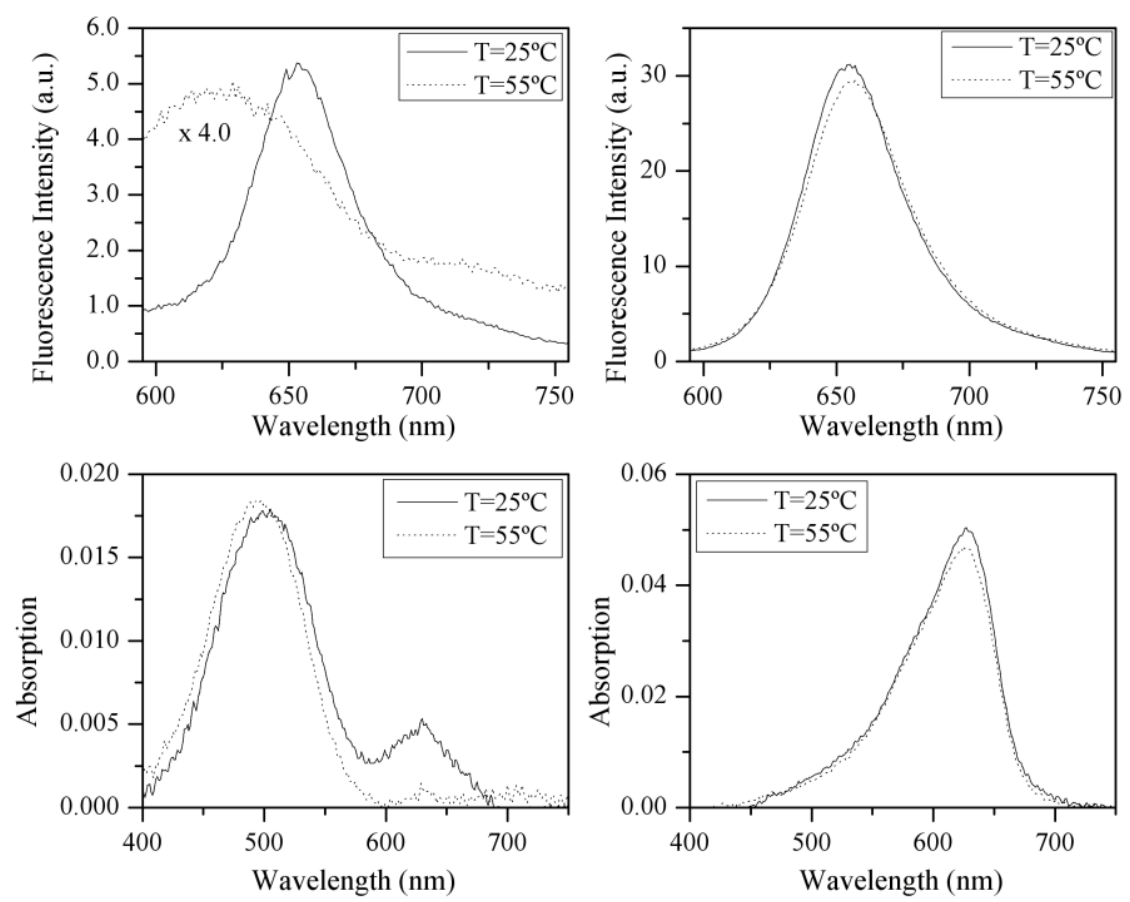

Figure 3. Absorption and fluorescence spectra of compound 1d in DODAB (left) and DPPC (right) vesicles below $\left(T=25^{\circ} \mathrm{C}\right)$ and above $\left(T=55^{\circ} \mathrm{C}\right)$ the gel to liquid-crystalline lipid phase transition. 

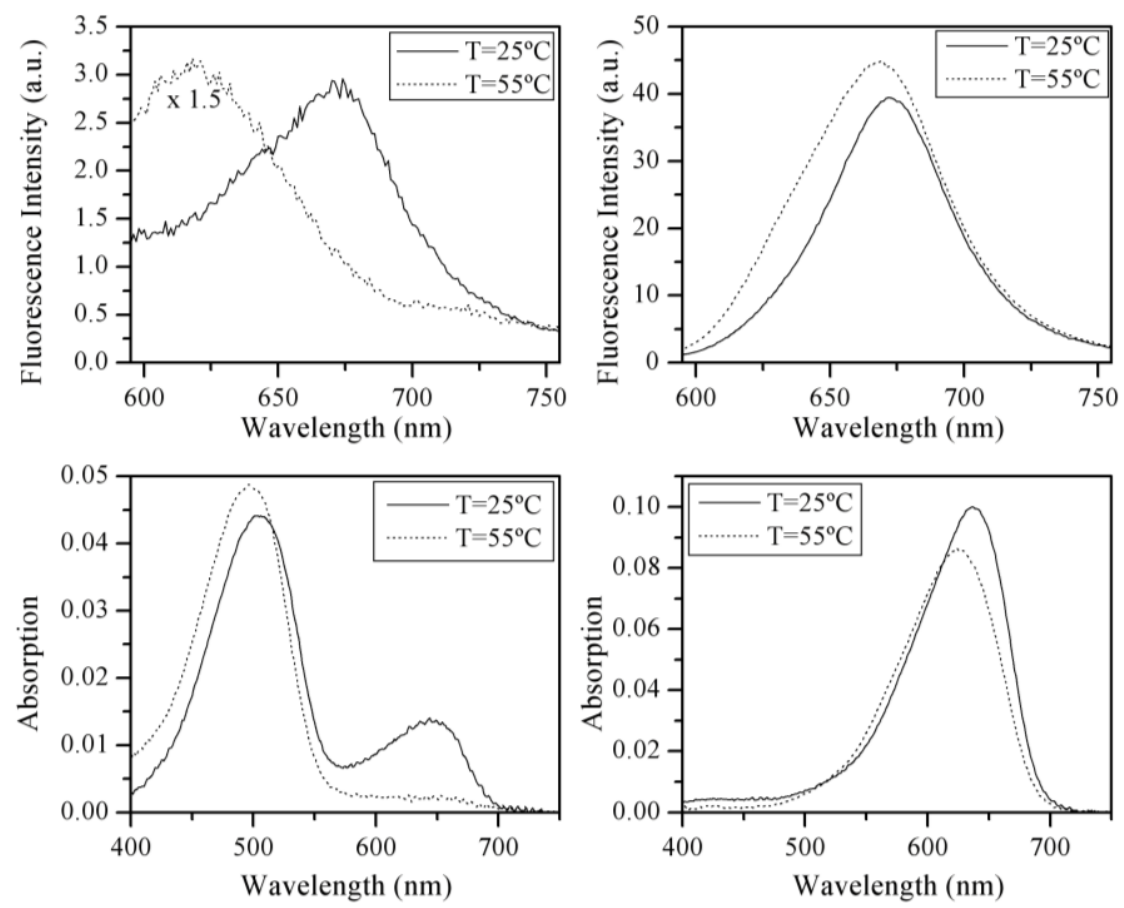

Figure 4. Absorption and fluorescence spectra of compound 1e in DODAB (left) and DPPC (right) vesicles below $\left(T=25^{\circ} \mathrm{C}\right)$ and above $\left(T=55^{\circ} \mathrm{C}\right)$ the gel to liquid-crystalline lipid phase transition.

\section{Conclusions}

In summary, 5,9-diaminobenzo[ $[a]$ phenoxazinium dyes 1a-e, possessing (di)icosylamino side-chains at 5or 9-positions of the polyaromatic system were efficiently synthesised. These dyes displayed strong absorption, and fluorescence emission in the near-infrared region with good fluorescence quantum yields. Results of photophysical behaviour in biomembranes showed that the absorption and fluorescence spectra depended on the charge of the biological membrane and on the lipid chains organization. As a result, the synthesised molecules were able to detect the gel to liquid-crystalline lipid phase transition by simple absorption and fluorescence measurements as well as to provide information on the charge of the membranes.

\section{Experimental Section}

General Information: All melting points were measured on a Stuart SMP3 melting point apparatus and are uncorrected. TLC analyses were carried out on $0.25 \mathrm{~mm}$ thick precoated silica plates (Merck Fertigplatten Kieselgel $60 \mathrm{~F}_{254}$ ) and spots were visualised under UV light or with the naked eye. Chromatography on silica gel was carried out on Merck Kieselgel (230-240 mesh). IR spectra were determined on a BOMEM MB 104 spectrophotometer, using $\mathrm{KBr}$ discs or neat samples. NMR spectra were obtained on a Varian Unity Plus Spectrometer, at an operating frequency of $300 \mathrm{MHz}$ for ${ }^{1} \mathrm{H} \mathrm{NMR}$ and $75.4 \mathrm{MHz}$ for ${ }^{13} \mathrm{C} \mathrm{NMR}$, or a Bruker Avance III 400, at an operating frequency of $400 \mathrm{MHz}$ for ${ }^{1} \mathrm{H}$ NMR and $100.6 \mathrm{MHz}$ for ${ }^{13} \mathrm{C}$ NMR using the 
solvent peak as an internal reference at $25^{\circ} \mathrm{C}$. All chemical shifts are given in ppm using $\delta_{\mathrm{H}} \mathrm{Me}_{4} \mathrm{Si}=0 \mathrm{ppm}$ as a reference and $J$ values are given in Hz. Assignments were made by comparison of chemical shifts, peak multiplicities and $J$ values and were supported by spin decoupling-double ressonance and bidimensional heteronuclear HMBC and HMQC correlation techniques. Mass spectrometry analyses were performed at the "C.A.C.T.I. - Unidad de Espectrometria de Masas", at the University of Vigo, Spain. UV-Visible absorption spectra $(200-800 \mathrm{~nm})$ were obtained using either a Shimadzu UV/2501PC or Shimadzu UV/3101PC spectrophotometers. Fluorescence spectra were collected using either FluoroMax-4 or FluoroMax-3 spectrofluorometers. All chemical reagents were used as received. Labelled vesicles were prepared by injection of an ethanolic solution containing the benzo $[a]$ phenoxazinium chloride 1a-e and either DODAB or DPPC into a required amount of an aqueous $\mathrm{pH} 7$ buffered solution. The injection was made above the gel to liquid crystalline phase transition and the DODAB/DPPC: dye molar ratio was kept at 500:1. The dye concentration was $2.0 \times 10^{-6} \mathrm{M}$. The resulting solutions were allowed to equilibrate for one day before absorption/fluorescence measurements were undertaken.

General method for the preparation of compounds 1a-e: To a cold solution (ice bath) of 5-(alkylamino)2-nitrosophenol hydrochloride 2a-e in ethanol (2-3 mL), $N$-alkylated-naphthylamine 3a,b and concentrated hydrochloride acid $\left(5.0 \times 10^{-2} \mathrm{~mL}\right)$ were added. The mixture was refluxed during 5 to 15 hours, and monitored by TLC (dichloromethane/methanol or chloroform/methanol). After evaporation of the solvent and column chromatography purification on silica gel, the required dye 1a-e was obtained as a blue material.

$N$-[5-(Icosylamino)-10-methyl-9H-benzo $[a]$ phenoxazin-9-ylide-ne $]$ ethanaminium chloride $1 \mathrm{a}$. The product of the reaction of $\mathbf{2 a}\left(0.085 \mathrm{~g}, 4.73 \times 10^{-4} \mathrm{~mol}\right)$ with $\mathbf{3 a}\left(0.20 \mathrm{~g}, 4.73 \times 10^{-4} \mathrm{~mol}\right)$ (reflux time $\left.5 \mathrm{~h}\right)$ was chromatographed with dichloromethane/ $n$-hexane and dichloromethane/methanol, mixtures of increasing polarity, as the eluent, to give compound $1 \mathbf{a}(0.20 \mathrm{~g}, 73 \%) . \mathrm{mp}=125.0-126.2{ }^{\circ} \mathrm{C}$. $\mathrm{TLC}$ (dichloromethane/methanol, 95:5): $R_{\mathrm{f}}=0.79 .{ }^{1} \mathrm{H} \mathrm{NMR}\left(\mathrm{CDCl}_{3}, 300 \mathrm{MHz}\right): \delta=0.86(\mathrm{t}, J=6.9 \mathrm{~Hz}, 3 \mathrm{H}$, $\left.\mathrm{NH}\left(\mathrm{CH}_{2}\right)_{19} \mathrm{CH}_{3}\right), 1.19-1.40\left(2 \times \mathrm{m}, 37 \mathrm{H}, 17 \times \mathrm{CH}_{2}\right.$ and $\left.\mathrm{NHCH}_{2} \mathrm{CH}_{3}\right), 1.81$ (br s, $\left.2 \mathrm{H}, \mathrm{NHCH}_{2} \mathrm{CH}_{2}\right), 2.40$ (s, 3 $\mathrm{H}, \mathrm{CH}_{3}$ ), 3.27 (br s, $2 \mathrm{H}, \mathrm{NHCH}_{2} \mathrm{CH}_{2}$ ), 3.47 (br s, $2 \mathrm{H}, \mathrm{NHCH}_{2} \mathrm{CH}_{3}$ ), 6.16 (s, $1 \mathrm{H}, 8-\mathrm{H}$ ), 6.22 (s, $1 \mathrm{H}, 6-\mathrm{H}$ ), 6.71 (br s, 1 H, NH), 7.37 (s, 1 H, 11-H), 7.70-7.90 (br s, 2 H, 2-H and 3-H ), 8.73 (d, J = 7.2 Hz, $1 \mathrm{H}, 1-\mathrm{H}$ ), 8.94 (br s, $1 \mathrm{H}, 4-\mathrm{H}), 10.34$ (br s, $1-\mathrm{H}, \mathrm{NH}) .{ }^{13} \mathrm{C} \mathrm{NMR}\left(\mathrm{CDCl}_{3}, 75.4 \mathrm{MHz}\right): \delta=13.84\left(\mathrm{NCH}_{2} \mathrm{CH}_{3}\right), 14.05$ $\left(\mathrm{N}\left(\mathrm{CH}_{2}\right)_{19} \mathrm{CH}_{3}\right), 18.29\left(\mathrm{CH}_{3}\right), 22.60\left(\mathrm{CH}_{2}\right), 27.10\left(\mathrm{NHCH}_{2} \mathrm{CH}_{2}\right), 28.60\left(\mathrm{CH}_{2}\right), 29.27\left(\mathrm{CH}_{2}\right), 29.30\left(\mathrm{CH}_{2}\right)$, $29.51\left(\mathrm{CH}_{2}\right), 29.55\left(\mathrm{CH}_{2}\right), 29.57\left(\mathrm{CH}_{2}\right), 29.62\left(\mathrm{CH}_{2}\right), 30.87\left(\mathrm{CH}_{2}\right), 31.84\left(\mathrm{CH}_{2}\right), 38.67\left(\mathrm{NHCH}_{2} \mathrm{CH}_{2}\right), 44.48$ $\left(\mathrm{NHCH}_{2} \mathrm{CH}_{3}\right.$ ), 92.29 (C-6), 93.08 (C-8), 123.44 (Ar-C), 123.98 (C-1), 125.10 (C-4), 127.00 (C-10), 129.67 (Ar-C), 129.93 (C-3), 130.55 (Ar-C), 131.01 (C-11), 131.54 (C-2), 133.38 (Ar-C), 146.76 (Ar-C), 150.57 (Ar-C), 154.10 (C-9), 156.80 (C-5). IR (KBr 1\%, $\left.\mathrm{cm}^{-1}\right): v=3450,3240,2956,2922,2852,1642,1591$, 1562, 1544, 1520, 1500, 1451, 1436, 1348, 1343, 1315, 1295, 1260, 1234, 1185, 1163, 1130, 1054, 1086, 1010, 881, 817, 773, 734, 708, 666. HRMS: m/z (EI): calcd for $\mathrm{C}_{39} \mathrm{H}_{58} \mathrm{~N}_{3} \mathrm{O}\left[\mathrm{M}^{+}\right]$: 584.45766; found: 584.45744 . 


\section{$N$-Ethyl- $N$-[5-(icosylamino)-9H-benzo[ $[a]$ phenoxazin-9-ylidene $]$}

ethanaminium chloride $\mathbf{1 b}$. The product of the reaction of $\mathbf{2 b}\left(0.092 \mathrm{~g}, 4.73 \times 10^{-4} \mathrm{~mol}\right)$, with $\mathbf{3 a}(0.20 \mathrm{~g}$, $4.73 \times 10^{-4}$ mol) (reflux time $9 \mathrm{~h}$ ) was chromatographed with dichloromethane/ $n$-hexane and dichloromethane/methanol, mixtures of increasing polarity, as the eluent, to give compound $\mathbf{1 b}(0.19 \mathrm{~g}$, $68 \%) . \mathrm{mp}=133.2-134.2{ }^{\circ} \mathrm{C} . \mathrm{TLC}$ (dichloromethane/methanol, 9:1): $R_{\mathrm{f}}=0.51 .{ }^{1} \mathrm{H} \mathrm{NMR}\left(\mathrm{CDCl}_{3}, 300 \mathrm{MHz}\right)$ : $\delta=0.84\left(\mathrm{t}, J=6.6 \mathrm{~Hz}, 3 \mathrm{H}, \mathrm{NH}\left(\mathrm{CH}_{2}\right)_{19} \mathrm{CH}_{3}\right), 1.10-1.30\left(\mathrm{~m}, 32 \mathrm{H}, 16 \times \mathrm{CH}_{2}\right), 1.31(\mathrm{t}, J=6.9 \mathrm{~Hz}, 3 \mathrm{H}$, $\left.\mathrm{N}\left(\mathrm{CH}_{2} \mathrm{CH}_{3}\right)_{2}\right), 1.45$ (br s, $\left.2 \mathrm{H}, \mathrm{CH}_{2}\right), 1.87$ (br s, $\left.2 \mathrm{H}, \mathrm{NHCH}_{2} \mathrm{CH}_{2}\right), 3.50-3.62$ (m, $\left.2 \mathrm{H}, \mathrm{N}\left(\mathrm{CH}_{2} \mathrm{CH}_{3}\right)_{2}\right), 3.77$ (br s, $\left.2 \mathrm{H}, \mathrm{NHCH}_{2} \mathrm{CH}_{2}\right), 6.48(\mathrm{~s}, 2 \mathrm{H}, 8-\mathrm{H}$ and 6-H), $6.92(\mathrm{~d}, J=9.0 \mathrm{~Hz}, 1 \mathrm{H}, 10-\mathrm{H}), 7.62(\mathrm{~d}, J=9.0 \mathrm{~Hz}, 1 \mathrm{H}$, 11-H ), 7.65-7.75 (m, $2 \mathrm{H}, 2-\mathrm{H}$ and 3-H), 8.55-8.65 (m, $1 \mathrm{H}, 1-\mathrm{H}), 9.26$ (br s, $1 \mathrm{H}, 4-\mathrm{H}) .{ }^{13} \mathrm{C} \mathrm{NMR}\left(\mathrm{CDCl}_{3}\right.$, $75.4 \mathrm{MHz}): \quad \delta=12.58\left(\mathrm{~N}_{\left.\left(\mathrm{CH}_{2} \mathrm{CH}_{3}\right)_{2}\right),} 13.98\left(\mathrm{NH}\left(\mathrm{CH}_{2}\right)_{19} \mathrm{CH}_{3}\right), 22.54\left(\mathrm{CH}_{2}\right), 27.13\left(\mathrm{CH}_{2}\right), 29.01\right.$ $\left(\mathrm{NHCH}_{2} \mathrm{CH}_{2}\right), 29.21\left(\mathrm{CH}_{2}\right), 29.30\left(\mathrm{CH}_{2}\right), 29.47\left(3 \times \mathrm{CH}_{2}\right), 29.51\left(4 \times \mathrm{CH}_{2}\right), 29.56\left(4 \times \mathrm{CH}_{2}\right), 31.77\left(2 \times \mathrm{CH}_{2}\right)$, $45.05\left(\mathrm{NHCH}_{2} \mathrm{CH}_{2}\right), 45.80\left(\mathrm{~N}\left(\mathrm{CH}_{2} \mathrm{CH}_{3}\right)_{2}\right), 93.20$ (C-6), 95.54 (C-8), 113.57 (C-10), 128.81 (C-1), 124.28 (Ar-C), 126.22 (C-4), 128.19 (Ar-C), 130.28 (C-3), 130.50 (Ar-C), 131.60 (C-2), 132.25 (C-11), 135.25 (ArC), 147.14 (Ar-C), 151.15 (Ar-C), 152.71 (C-9), 158.29 (C-5). IR ( $\left.\mathrm{KBr} 1 \%, \mathrm{~cm}^{-1}\right): v=3440,2955,2921$, 2851, 1640, 1588, 1548, 1494, 1461, 1436, 1384, 1328, 1276, 1257, 1166, 1123, 1075, 1013, 947, 865, 757, 700, 666. HRMS: m/z (EI): calcd for $\mathrm{C}_{40} \mathrm{H}_{60} \mathrm{~N}_{3} \mathrm{O}\left[\mathrm{M}^{+}\right]$: 598.47259; found: 598.47309.

$N$-[5-(Icosylamino)-9H-benzo[ $[a]$ phenoxazin-9-ylidene]- $N$-methylmethanaminium chloride 1c. The product of the reaction of $\mathbf{2 c}\left(0.072 \mathrm{~g}, 4.74 \times 10^{-4} \mathrm{~mol}\right)$, with $\mathbf{3 a}\left(0.201 \mathrm{~g}, 4.74 \times 10^{-4} \mathrm{~mol}\right)$ (reflux time $\left.7 \mathrm{~h}\right)$ was chromatographed with dichloromethane/ $n$-hexane and dichloromethane/methanol, mixtures of increasing polarity, as the eluent, to give compound 1c $(0.23 \mathrm{~g}, 85 \%) . \mathrm{mp}=171.2-173.7{ }^{\circ} \mathrm{C}$. $\mathrm{TLC}$ (dichloromethane/methanol, 9.5:0.5): $R_{\mathrm{f}}=0.37 .{ }^{1} \mathrm{H} \mathrm{NMR}\left(\mathrm{CDCl}_{3}, 300 \mathrm{MHz}\right): \delta=0.83(\mathrm{t}, J=6.6 \mathrm{~Hz}, 3 \mathrm{H}$, $\left.\mathrm{NH}\left(\mathrm{CH}_{2}\right)_{19} \mathrm{CH}_{3}\right), 1.10-1.50\left(2 \times \mathrm{m}, 34 \mathrm{H}, 17 \times \mathrm{CH}_{2}\right), 1.76-1.90\left(\mathrm{~m}, 2 \mathrm{H}, \mathrm{NHCH}_{2} \mathrm{CH}_{2}\right), 3.24\left(\mathrm{~s}, 6 \mathrm{H}, \mathrm{N}\left(\mathrm{CH}_{3}\right)_{2}\right)$, 3.60-3.76 (m, $2 \mathrm{H}, \mathrm{NHCH}_{2} \mathrm{CH}_{2}$ ), 4.62 (br s, $\left.1 \mathrm{H}, \mathrm{NH}\right), 6.31$ (d, J = 2.7 Hz, $1 \mathrm{H}, 8-\mathrm{H}$ ), 6.38 (s, $1 \mathrm{H}, 6-\mathrm{H}$ ), $6.92(\mathrm{dd}, J=9.0$ and $2.4 \mathrm{~Hz}, 1 \mathrm{H}, 10-\mathrm{H}), 7.49(\mathrm{~d}, J=9.3 \mathrm{~Hz}, 1 \mathrm{H}, 11-\mathrm{H}), 7.56-7.70$ (m, $2 \mathrm{H}, 2-\mathrm{H}$ and 3-H), $8.51(\mathrm{~d}, J=8.1$ and $1.2 \mathrm{~Hz}, 1 \mathrm{H}, 1-\mathrm{H}), 8.95(\mathrm{~d}, J=7.8 \mathrm{~Hz}, 1 \mathrm{H}, 4-\mathrm{H}) .{ }^{13} \mathrm{C} \mathrm{NMR}\left(\mathrm{CDCl}_{3}, 75.4 \mathrm{MHz}\right): \delta=$ $13.95\left(\mathrm{NH}\left(\mathrm{CH}_{2}\right)_{19} \mathrm{CH}_{3}\right), 22.51\left(\mathrm{CH}_{2}\right), 27.07\left(\mathrm{CH}_{2}\right), 28.95\left(\mathrm{CH}_{2}\right), 29.18\left(2 \times \mathrm{CH}_{2}\right), 29.30\left(\mathrm{CH}_{2}\right), 29.48$

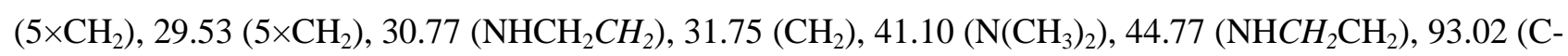
6), 95.68 (C-8), 114.35 (C-10), 123.62 (Ar-C), 123.88 (C-1), 125.36 (C-4), 128.62 (Ar-C), 129.93 (Ar-C), 130.30 (C-3), 131.61 (C-11), 131.90 (C-2), 134.39 (Ar-C), 146.63 (Ar-C), 150.88 (Ar-C), 154.63 (C-9), $157.67(\mathrm{C}-5)$. IR $\left(\mathrm{KBr} 1 \%, \mathrm{~cm}^{-1}\right): v=3439,2955,2920,2851,1657,1642,1589,1552,1537,1513,1494$, 1463, 1427, 1383, 1330, 1291, 1204, 1178, 1149, 1125, 1010, 905, 865, 850, 836, 773, 741, 715, 666. HRMS: $\mathrm{m} / \mathrm{z}$ (EI): calcd for $\mathrm{C}_{38} \mathrm{H}_{56} \mathrm{~N}_{3} \mathrm{O}\left[\mathrm{M}^{+}\right]$: 570.44321 ; found: 570.44179 .

$N$-[5-(Propylamino)-9H-benzo[a]phenoxazin-9-ylidene]icosan-1-aminium chloride 1d. The product of the reaction of $\mathbf{2 d}\left(0.505 \mathrm{~g}, 1.13 \times 10^{-3} \mathrm{~mol}\right)$ with $\mathbf{3 b}\left(0.148 \mathrm{~g}, 8.0 \times 10^{-2} \mathrm{~mol}\right)$ (reflux time $\left.12 \mathrm{~h}\right)$ was chromatographed with chloroform and chloroform/methanol, mixtures of increasing polarity, as the eluent, to give compound $\mathbf{1 d}(0.185 \mathrm{~g}, 37 \%) . \mathrm{mp}=87-89^{\circ} \mathrm{C}$. TLC (chloroform/methanol, 9:1): $R_{\mathrm{f}}=0.55 .{ }^{1} \mathrm{H} \mathrm{NMR}$ 
$\left(\mathrm{CDCl}_{3}, 400 \mathrm{MHz}\right): \delta=0.87\left(\mathrm{t}, J=7.2 \mathrm{~Hz}, 3 \mathrm{H}, \mathrm{NH}\left(\mathrm{CH}_{2}\right)_{19} \mathrm{CH}_{3}\right), 1.07$ (t, $\left.J=7.2 \mathrm{~Hz}, 3 \mathrm{H}, \mathrm{NHCH}_{2} \mathrm{CH}_{2} \mathrm{CH}_{3}\right)$, 1.10-1.45 (m, $34 \mathrm{H}, \mathrm{NHCH}_{2} \mathrm{CH}_{2}\left(\mathrm{CH}_{2}\right)_{17} \mathrm{CH}_{3}$ ), 1.73 (br s, $2 \mathrm{H}, \mathrm{NHCH}_{2} \mathrm{CH}_{2}\left(\mathrm{CH}_{2}\right)_{17} \mathrm{CH}_{3}$ ), 1.90 (br s, $2 \mathrm{H}$, $\mathrm{NHCH}_{2} \mathrm{CH}_{2} \mathrm{CH}_{3}$ ), 3.03 (br s, $2 \mathrm{H}, \mathrm{NHCH}_{2} \mathrm{CH}_{2}\left(\mathrm{CH}_{2}\right)_{17} \mathrm{CH}_{3}$ ), 3.49 (br s, $2 \mathrm{H}, \mathrm{NHCH} \mathrm{CH}_{2} \mathrm{CH}_{3}$ ), 6.10 (br s, $1 \mathrm{H}$, 8-H), 6.16 (br s, $1 \mathrm{H}, 6-\mathrm{H}), 7.11$ (br s, $1 \mathrm{H}, 10-\mathrm{H}), 7.34$ (d, J = 8.0 Hz, $1 \mathrm{H}, 11-\mathrm{H}), 7.74$ (br s, $3 \mathrm{H}, 3-\mathrm{H}, 2-\mathrm{H}$, $\mathrm{N}-\mathrm{H}), 8.32$ (br s, $1 \mathrm{H}, \mathrm{NH}), 8.64(\mathrm{~d}, J=6.8 \mathrm{~Hz}, 1 \mathrm{H}, 4-\mathrm{H}), 8.85$ (br s, $1 \mathrm{H}, 1-\mathrm{H}) .{ }^{13} \mathrm{C} \mathrm{NMR}\left(\mathrm{CDCl}_{3}, 100.6\right.$ $\mathrm{MHz}): \delta=11.59\left(\mathrm{NHCH}_{2} \mathrm{CH}_{2} \mathrm{CH}_{3}\right), 14.09\left(\mathrm{NH}\left(\mathrm{CH}_{2}\right)_{19} \mathrm{CH}_{3}\right), 21.98\left(\mathrm{NHCH}_{2} \mathrm{CH}_{2} \mathrm{CH}_{3}\right), 22.66\left(\mathrm{CH}_{2}\right), 27.17$ $\left(\mathrm{CH}_{2}\right), 28.48\left(\mathrm{NHCH}_{2} \mathrm{CH}_{2}\left(\mathrm{CH}_{2}\right)_{17} \mathrm{CH}_{3}\right), 29.33\left(\mathrm{CH}_{2}\right), 29.59\left(2 \times \mathrm{CH}_{2}\right), 29.63\left(4 \times \mathrm{CH}_{2}\right), 29.68\left(4 \times \mathrm{CH}_{2}\right), 31.90$ $\left(4 \times \mathrm{CH}_{2}\right), 43.89\left(\mathrm{NHCH}_{2} \mathrm{CH}_{2}\left(\mathrm{CH}_{2}\right)_{17} \mathrm{CH}_{3}\right), 46.29\left(\mathrm{NHCH}_{2} \mathrm{CH}_{2} \mathrm{CH}_{3}\right), 92.40$ (C-6), 94.07 (C-8), 118.03 (C-10), 123.47 (Ar-C), 123.78 (C-4), 125.33 (C-1), 129.52 (C-3), 130.13 (Ar-C), 130.69 (C-2), 131.35 (Ar-C), 131.65 (C-11), 132.51 (Ar-C), 147.80 (Ar-C), 150.43 (Ar-C), 155.93 (C-9), 157.12 (C-5). IR (KBr 1\%, cm $\left.{ }^{1}\right): v=3402,3203,2918,2850,1642,1590,1547,1495,1467,1432,1384,1321,1283,1256,1237,1186$, 1161, 1122, 1012, 1000, 975, 823, 771, 718, 666. HRMS: m/z (FAB): calcd for $\mathrm{C}_{39} \mathrm{H}_{58} \mathrm{~N}_{3} \mathrm{O}\left[\mathrm{M}^{+}+1\right]$ : 584.45724; found: 584.45744 .

$N$-Icosyl- $N$-[5-(propylamino)-9H-benzo $[a]$ phenoxazin-9-ylidene $]$ icosan-1-aminium chloride 1 e. The product of the reaction of $2 \mathbf{e}\left(0.500 \mathrm{~g}, 7.1 \times 10^{-4} \mathrm{~mol}\right)$ with $\mathbf{3 b}\left(0.88 \mathrm{~g}, 4.8 \times 10^{-4} \mathrm{~mol}\right)$ (reflux time $\left.15 \mathrm{~h}\right)$ was chromatographed with chloroform and chloroform/methanol, mixtures of increasing polarity, as the eluent, to give compound 1e $(0.303 \mathrm{~g}, 70 \%) . \mathrm{mp}=140-142^{\circ} \mathrm{C}$. TLC (chloroform/methanol, 94:6): $R_{\mathrm{f}}=0.26 .{ }^{1} \mathrm{H} \mathrm{NMR}$ $\left(\mathrm{CDCl}_{3}, 400 \mathrm{MHz}\right): \delta=0.87\left(\mathrm{t}, J=7.2 \mathrm{~Hz}, 6 \mathrm{H}, 2 \times \mathrm{N}\left(\mathrm{CH}_{2}\right)_{19} \mathrm{CH}_{3}\right), 1.09$ (br s, $\left.3 \mathrm{H}, \mathrm{NHCH}_{2} \mathrm{CH}_{2} \mathrm{CH}_{3}\right), 1.20$ $1.50\left(\mathrm{~m}, 68 \mathrm{H}, 2 \times \mathrm{NCH}_{2} \mathrm{CH}_{2}\left(\mathrm{CH}_{2}\right)_{17} \mathrm{CH}_{3}\right), 1.71$ (br s, $4 \mathrm{H}, 2 \times \mathrm{NCH}_{2} \mathrm{CH}_{2}\left(\mathrm{CH}_{2}\right)_{17} \mathrm{CH}_{3}$ ), 1.95 (br s, $2 \mathrm{H}$, $\mathrm{NHCH}_{2} \mathrm{CH}_{2} \mathrm{CH}_{3}$ ), 3.49 (br s, $4 \mathrm{H}, 2 \times \mathrm{NCH}_{2} \mathrm{CH}_{2}\left(\mathrm{CH}_{2}\right.$ ) ${ }_{17} \mathrm{CH}_{3}$ ), 3.81 (br s, $2 \mathrm{H}, \mathrm{NHCH}_{2} \mathrm{CH}_{2} \mathrm{CH}_{3}$ ), 6.55 (br s, 1 H, 8-H), 6.61 (br s, $1 \mathrm{H}, 6-\mathrm{H}), 6.95$ (d, $J=8.4 \mathrm{~Hz}, 1 \mathrm{H}, 10-\mathrm{H}), 7.70-7.90$ (m, $3 \mathrm{H}, 11-\mathrm{H}, 3-\mathrm{H}$ and 2-H), 8.73 (br s, $1 \mathrm{H}, 4-\mathrm{H}), 9.30$ (br s, $1 \mathrm{H}, 1-\mathrm{H}), 11.68$ (br s, $1 \mathrm{H}, \mathrm{NH}) .{ }^{13} \mathrm{C} \mathrm{NMR}\left(\mathrm{CDCl}_{3}, 100.6 \mathrm{MHz}\right): \delta=11.55$ $\left(\mathrm{NHCH}_{2} \mathrm{CH}_{2} \mathrm{CH}_{3}\right), 14.05\left(2 \times \mathrm{N}\left(\mathrm{CH}_{2}\right)_{19} \mathrm{CH}_{3}\right), 22.33\left(5 \times \mathrm{CH}_{2}\right), 22.62\left(\mathrm{NHCH}_{2} \mathrm{CH}_{2} \mathrm{CH}_{3}\right), 26.97\left(5 \times \mathrm{CH}_{2}\right), 27.40$ $\left(2 \times \mathrm{NCH}_{2} \mathrm{CH}_{2}\left(\mathrm{CH}_{2}\right)_{17} \mathrm{CH}_{3}\right), 29.29\left(4 \times \mathrm{CH}_{2}\right), 29.38\left(4 \times \mathrm{CH}_{2}\right), 29.53\left(4 \times \mathrm{CH}_{2}\right), 29.59\left(4 \times \mathrm{CH}_{2}\right), 29.64\left(4 \times \mathrm{CH}_{2}\right)$, $31.85\left(4 \times \mathrm{CH}_{2}\right), 46.51\left(\mathrm{NHCH}_{2} \mathrm{CH}_{2} \mathrm{CH}_{3}\right), 52.02\left(2 \times \mathrm{NCH}_{2} \mathrm{CH}_{2}\left(\mathrm{CH}_{2}\right)_{17} \mathrm{CH}_{3}\right), 93.44(\mathrm{C}-6), 95.81(\mathrm{C}-8), 113.69$ (C-10), 124.03 (C-4), 124.23 (Ar-C), 126.33 (C-1), 128.41 (2×Ar-C), 130.70 (C-3), 131.95 (C-2), 132.39 (C11), 135.61 (Ar-C), 147.33 (Ar-C), 151.52 (Ar-C), 153.14 (C-9), $158.76(\mathrm{C}-5)$. IR (KBr 1\%, $\left.\mathrm{cm}^{-1}\right): v=3430$, 2955, 2918, 2850, 1638, 1590, 1548, 1490, 1466, 1434, 1384, 1330, 1288, 1236, 1182, 1163, 1124, 1016, 1000, 721, 666. HRMS: m/z (FAB): calcd for $\mathrm{C}_{59} \mathrm{H}_{98} \mathrm{~N}_{3} \mathrm{O}$ [M+1]: 864.76994; found: 864.77044 .

General method for preparation of compounds $2 d$ and 2e: To an ice-cold solution of the 3((di)icosylamino)phenol in ethanol, concentrated hydrochloric acid was added and stirred until the reaction mixture became homogenous. The solution of sodium nitrite in water was then added drop-wise within an interval of $20 \mathrm{~min}$. The resulting mixture was stirred for the time mentioned and monitored by TLC (dichloromethane/methanol, 95:5). After evaporation of the reaction, the 5-((di)icosylamino)-2-nitrosophenol hydrochloride $\mathbf{2 d}$ or $\mathbf{2 e}$ was obtained as a yellow solid and was used in the following step without any purification. 
5-(Icosylamino)-2-nitrosophenol hydrochloride 2d. From the reaction of 3-(icosylamino)phenol (0.392 g, $\left.1 \times 10^{-3} \mathrm{~mol}\right)$ in ethanol $(4 \mathrm{~mL})$ and concentrated hydrochloric acid $(0.2 \mathrm{~mL})$ with sodium nitrite $(0.076 \mathrm{~g}$, $\left.1.1 \times 10^{-3} \mathrm{~mol}\right)$ in water $(0.4 \mathrm{~mL})$, compound $2 \mathrm{~d}$ was obtained $(0.418 \mathrm{~g} ; 98 \%)$.

5-(Diicosylamino)-2-nitrosophenol hydrochloride 2e. From the reaction of 3-(diicosylamino)phenol (0.300 $\left.\mathrm{g}, 4.5 \times 10^{-4} \mathrm{~mol}\right)$ in ethanol $(3 \mathrm{~mL})$ and concentrated hydrochloric acid $(0.2 \mathrm{~mL})$ with sodium nitrite $(0.040 \mathrm{~g}$; $\left.5.8 \times 10^{-4} \mathrm{~mol}\right)$ in water $(0.1 \mathrm{~mL})$, compound $2 \mathrm{e}$ was obtained $(0.290 \mathrm{~g} ; 93 \%)$.

Synthesis of 3-(icosylamino)phenol and 3-(diicosylamino)phenol: To a solution of 3-aminophenol (1.0 g, $\left.9.1 \times 10^{-3} \mathrm{~mol}\right)$ in ethanol $(5 \mathrm{~mL}), 1$-bromoicosane $\left(3.976 \mathrm{~g}, 1.08 \times 10^{-2} \mathrm{~mol}\right)$ was added and the reaction mixture was refluxed for $44 \mathrm{~h}$. After purification by column chromatography on silica gel with chloroform and chloroform/methanol as the eluent, 3-(icosylamino)phenol was obtained as a white solid (2.466 g, 70\%), $\mathrm{mp}=81.7-83.7^{\circ} \mathrm{C}$. TLC (dichloromethane): $R_{\mathrm{f}}=0.14 .{ }^{1} \mathrm{H} \mathrm{NMR}\left(\mathrm{CDCl}_{3}, 400 \mathrm{MHz}\right): \delta=0.89(\mathrm{t}, J=6.8 \mathrm{~Hz}$, $\left.3 \mathrm{H}, \mathrm{N}\left(\mathrm{CH}_{2}\right)_{19} \mathrm{CH}_{3}\right), 1.25-1.40\left(\mathrm{~m}, 34 \mathrm{H}, \mathrm{NCH}_{2} \mathrm{CH}_{2}\left(\mathrm{CH}_{2}\right)_{17} \mathrm{CH}_{3}\right), 1.56-1.65\left(\mathrm{~m}, 2 \mathrm{H}, \mathrm{NCH}_{2} \mathrm{CH}_{2}\left(\mathrm{CH}_{2}\right)_{17} \mathrm{CH}_{3}\right)$, 3.08 (t, $\left.J=7.2 \mathrm{~Hz}, 2 \mathrm{H}, \mathrm{NCH}_{2} \mathrm{CH}_{2}\left(\mathrm{CH}_{2}\right)_{17} \mathrm{CH}_{3}\right), 3.65$ (t, $\left.J=7.2 \mathrm{~Hz}, 1 \mathrm{H}, \mathrm{NH}\right), 4.60$ (br s, $\left.1 \mathrm{H}, \mathrm{OH}\right), 6.10$ (t, $J=2.0 \mathrm{~Hz}, 1 \mathrm{H}, 2-\mathrm{H}), 6.16(\mathrm{dd}, J=8.0 \mathrm{~Hz}, J=2.0 \mathrm{~Hz}, 1 \mathrm{H}, 4-\mathrm{H}), 6.20(\mathrm{dd}, J=8.4$ and $2.0 \mathrm{~Hz}, 1 \mathrm{H}, 6-\mathrm{H})$,

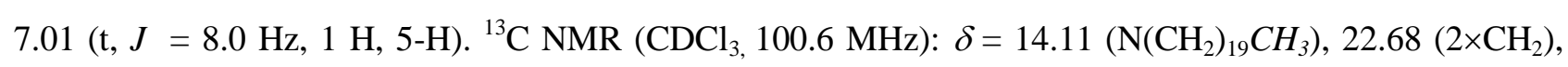
$27.15\left(\mathrm{NCH}_{2} \mathrm{CH}_{2}\left(\mathrm{CH}_{2}\right)_{17} \mathrm{CH}_{3}\right), 29.35\left(2 \times \mathrm{CH}_{2}\right), 29.44\left(2 \times \mathrm{CH}_{2}\right), 29.51\left(2 \times \mathrm{CH}_{2}\right), 29.59\left(2 \times \mathrm{CH}_{2}\right), 29.60$ $\left(2 \times \mathrm{CH}_{2}\right), 29.65\left(2 \times \mathrm{CH}_{2}\right), 29.69\left(2 \times \mathrm{CH}_{2}\right), 31.92\left(\mathrm{CH}_{2}\right), 43.96\left(\mathrm{NCH}_{2} \mathrm{CH}_{2}\left(\mathrm{CH}_{2}\right)_{17} \mathrm{CH}_{3}\right), 99.35(\mathrm{C}-2), 103.98$ (C-4), 105.90 (C-6), 130.12 (C-5), 150.15 (C-3), 156.69 (C-1). IR $\left(\mathrm{KBr} 1 \%, \mathrm{~cm}^{-1}\right): v=3372,3274,2954$, 2918, 2849, 1631, 1594, 1518, 1505, 1486, 1473, 1464, 1391, 1374, 1333, 1252, 1239, 1205, 1191, 1165, 994, 946, 853, 846, 753, 729, 720, 688, 666. HRMS: m/z (FAB): calcd for $\mathrm{C}_{26} \mathrm{H}_{48} \mathrm{NO}\left[\mathrm{M}^{+}+1\right]$ : 390.3718; found: 390.37240 .

In addition to the 3-(icosylamino)phenol, 3-(diicosylamino)phenol was also obtained as a purple solid $(1.582 \mathrm{~g}, 26 \%) . \mathrm{Mp}=55.7-57.7^{\circ} \mathrm{C} . R_{\mathrm{f}}=0.20$ (dichloromethane). $\mathrm{IR}\left(\mathrm{KBr} 1 \%, \mathrm{~cm}^{-1}\right): v=3496,3383,2918$, 2850, 1618, 1578, 1503, 1467, 1399, 1373, 1297, 1282, 1270, 1257, 1240, 1224, 1209, 1193, 1181, 1170, 1147, 1110, 1090, 1033, 999, 829, 720, 755, 689, $666 \mathrm{~cm}^{-1} .{ }^{1} \mathrm{H} \mathrm{NMR}\left(\mathrm{CDCl}_{3}, 400 \mathrm{MHz}\right): \delta=0.89(\mathrm{t}, J=6.8$ $\left.\mathrm{Hz}, \quad 6 \mathrm{H}, \quad 2 \times \mathrm{N}\left(\mathrm{CH}_{2}\right)_{19} \mathrm{CH}_{3}\right), \quad 1.10-1.50\left(\mathrm{~m}, 68 \mathrm{H}, \quad 2 \times \mathrm{NCH}_{2} \mathrm{CH}_{2}\left(\mathrm{CH}_{2}\right)_{17} \mathrm{CH}_{3}\right), \quad 1.58$ (br s, $4 \mathrm{H}$, $2 \times \mathrm{NCH}_{2} \mathrm{CH}_{2}\left(\mathrm{CH}_{2}\right)_{17} \mathrm{CH}_{3}$ ), 3.22 (t, $J=8.0 \mathrm{~Hz}, 4 \mathrm{H}, 2 \times \mathrm{NCH}_{2} \mathrm{CH}_{2}\left(\mathrm{CH}_{2}\right)_{17} \mathrm{CH}_{3}$ ), 4.56 (br s, $\left.1 \mathrm{H}, \mathrm{OH}\right), 6.09$ (dd, $J=8.0$ and $2.4 \mathrm{~Hz}, 1 \mathrm{H}, 4-\mathrm{H}), 6.12(\mathrm{t}, J=2.0 \mathrm{~Hz}, 1 \mathrm{H}, 2-\mathrm{H}), 6.23(\mathrm{dd}, J=8.4$ and $2.4 \mathrm{~Hz}, 1 \mathrm{H}, 6-\mathrm{H}), 7.04$ (t, $J=8.0 \mathrm{~Hz}, 1 \mathrm{H}, 5-\mathrm{H}) .{ }^{13} \mathrm{C} \mathrm{NMR}\left(\mathrm{CDCl}_{3}, 100.6 \mathrm{MHz}\right): \delta=14.11\left(2 \times \mathrm{N}\left(\mathrm{CH}_{2}\right){ }_{19} \mathrm{CH}_{3}\right), 22.69\left(4 \times \mathrm{CH}_{2}\right), 27.19$ $\left(2 \times \mathrm{NCH}_{2} \mathrm{CH}_{2}\left(\mathrm{CH}_{2}\right)_{17} \mathrm{CH}_{3}\right), 27.27\left(4 \times \mathrm{CH}_{2}\right), 29.36\left(4 \times \mathrm{CH}_{2}\right), 29.56\left(4 \times \mathrm{CH}_{2}\right), 29.63\left(4 \times \mathrm{CH}_{2}\right), 29.71\left(12 \times \mathrm{CH}_{2}\right)$, $31.93\left(2 \times \mathrm{CH}_{2}\right), 51.11\left(2 \times \mathrm{NCH}_{2} \mathrm{CH}_{2}\left(\mathrm{CH}_{2}\right)_{17} \mathrm{CH}_{3}\right), 98.49$ (C-2), 102.00 (C-4), 104.65 (C-6), 130.01 (C-5), 149.82 (C-3), 156.66 (C-1). HRMS: m/z (ESI): calcd. for $\mathrm{C}_{46} \mathrm{H}_{88} \mathrm{NO}\left[\mathrm{M}^{+}+1\right] 670.68544$; found: 670.68604 .

$N$-Icosylnaphthalen-1-amine 3a: To a solution of naphthalen-1-amine $\left(1.01 \mathrm{~g} ; 6.98 \times 10^{-3} \mathrm{~mol}\right)$ in ethanol (2 $\mathrm{mL}), 1$-bromoicosane $\left(2.65 \mathrm{~g}, 7.33 \times 10^{-3} \mathrm{~mol}\right)$ was added and the resulting mixture was refluxed for $17 \mathrm{~h} 30$ 
min, and monitored by TLC (chloroform/n-hexane, 7:3). The solvent was evaporated and the crude mixture was purified by column chromatography on silica gel using chloroform $/ n$-hexane, mixtures of increasing polarity, as the eluent, to give compound 3a as a white oily solid $(2.66 \mathrm{~g}, 90 \%) . R_{\mathrm{f}}=0.69$ (chloroform $/ n$ hexane, 7:3). IR (neat, $\mathrm{cm}^{-1}$ ): $v=3397,2954,2917,2849,1620,1583,1523,1466,1409,1380,1283,1253$, 1140, 1120, 785, 768, 722, $666 \mathrm{~cm}^{-1} .{ }^{1} \mathrm{H}$ NMR $\left(\mathrm{CDCl}_{3}, 300 \mathrm{MHz}\right): \delta=0.90(\mathrm{t}, J=6.9 \mathrm{~Hz}, 3 \mathrm{H}$, $\left.\mathrm{NH}\left(\mathrm{CH}_{2}\right)_{19} \mathrm{CH}_{3}\right), 1.40-1.50$ (m, $\left.34 \mathrm{H}, \mathrm{NHCH}_{2} \mathrm{CH}_{2}\left(\mathrm{CH}_{2}\right)_{1} 7 \mathrm{CH}_{3}\right), 1.72-1.86$ (m, $\left.2 \mathrm{H}, \mathrm{NHCH}_{2} \mathrm{CH}_{2}\left(\mathrm{CH}_{2}\right)_{17} \mathrm{CH}_{3}\right)$, $3.30\left(\mathrm{t}, J=6.9 \mathrm{~Hz}, 2 \mathrm{H}, \mathrm{NHCH} \mathrm{CH}_{2}\left(\mathrm{CH}_{2}\right)_{17} \mathrm{CH}_{3}\right), 6.73($ br s, $1 \mathrm{H}, 4-\mathrm{H}), 7.28(\mathrm{~d}, J=7.8 \mathrm{~Hz}, 1 \mathrm{H}, 2-\mathrm{H}), 7.37$ (t, $J=7.8 \mathrm{~Hz}, 1 \mathrm{H}, 3-\mathrm{H}), 7.42-7.50$ (m, $2 \mathrm{H}, 6-\mathrm{H}$ and 7-H), 7.78-7.82 (m, $1 \mathrm{H}, 8-\mathrm{H})$, 7.84-7.90 (m, $1 \mathrm{H}, 5-\mathrm{H})$.

${ }^{13} \mathrm{C} \mathrm{NMR}\left(\mathrm{CDCl}_{3}, 75.4 \mathrm{MHz}\right): \delta=14.11\left(\mathrm{NH}\left(\mathrm{CH}_{2}\right){ }_{19} \mathrm{CH}_{3}\right), 22.68\left(2 \times \mathrm{CH}_{2}\right), 26.63\left(2 \times \mathrm{CH}_{2}\right), 27.14\left(\mathrm{CH}_{2}\right)$, $27.94\left(\mathrm{CH}_{2}\right), 28.31\left(\mathrm{NHCH}_{2} \mathrm{CH}_{2}\left(\mathrm{CH}_{2}\right)_{17} \mathrm{CH}_{3}\right), 29.22\left(\mathrm{CH}_{2}\right), 29.32\left(\mathrm{CH}_{2}\right), 29.35\left(\mathrm{CH}_{2}\right), 29.53\left(\mathrm{CH}_{2}\right), 29.56$ $\left(\mathrm{CH}_{2}\right), 29.69\left(\mathrm{CH}_{2}\right), 30.91\left(\mathrm{CH}_{2}\right), 31.91\left(\mathrm{CH}_{2}\right), 43.19\left(\mathrm{CH}_{2}\right), 46.57\left(\mathrm{CH}_{2}\right), 48.82\left(\mathrm{CH}_{2}\right), 53.00$ $\left(\mathrm{NHCH}_{2} \mathrm{CH}_{2}\left(\mathrm{CH}_{2}\right)_{17} \mathrm{CH}_{3}\right), 117.85$ (C-4), 120.33 (C-5), 122.21 (C-2), 124.14 (C-4a), 126.05 (C-7), 126.17 (C-6), 126.71 (C-3), 128.69 (C-8), 134.34 (C-8a), 138.03 (C-1). HRMS: m/z (EI): calcd. for $\mathrm{C}_{30} \mathrm{H}_{49} \mathrm{~N}$ [M $\left.{ }^{+}\right]$ 423.3865; found 423.3866 .

\section{Acknowledgments}

Thanks are due to Fundação para a Ciência e Tecnologia (Portugal) for its financial support of a BPD to Sarala Naik (SFRH/BPD/37840/2007), Centro de Química and Centro de Física (Universidade do Minho). The NMR spectrometer Bruker Avance III 400 is part of the National NMR Network and was purchased in the framework of the National Program for Scientific Re-equipment, contract REDE/1517/RMN/2005, with funds from POCI 2010 (FEDER) and FCT.

[1] O. G. Mouritsen in As a Matter of Fat-The Emerging Science of Lipidomics; Springer-Verlag, Heidelberg, 2005.

[2] J. Katsaras, T. Gutberlet, Lipid Bilayers: Structure and Interactions, Springer-Verlag, Berlin, 2001.

[3] R. B. Gennis, Biomembranes: Molecular Structure and Function, Springer-Verlag, New York, 1989.

[4] A. P. Demchenko, Y. Mély, G. Duportail, A. S. Klymchenko, Biophys. J. 2009, 96, 3461-3470.

[5] J. Repáková, J. M. Holopainen, M. Karttunen, I. Vattulainen, J. Phys. Chem. B 2006, 110, 1540315410.

[6] D. M. Owen, M. A. A. Neil, P. M. W. French, A. I. Magee, Semin. CellDev. Biol. 2007, 18, 591-598.

[7] A. S. Klymchenko, S. Oncul, P. Didier, E. Schaub, L. Bagatolli, G. Duportail, V. Mély, Biochim. Biophys. Acta 2009, 1788, 495-499.

[8] S. Oncul, A. S. Klymchenko, O. A. Kucherak, A. P. Demchenko, S. Martin, M. Dontenwill, Y. Arntz, P. Didier, G. Duportail, Y. Mély, Biochim. Biophys. Acta 2010, 1798, 1436-1443. 
[9] H. Ishii, T. Shimanouchi, H. Umakoshi, P. Walde, R. Kuboi, Colloid Surface B 2010, 77, 117-121.

[10] H. Bouvrais, T. Pott, L. A. Bagatolli, J. H. Ipsen, P. Méléard, Biochim. Biophys. Acta 2010, 1798, 1333-1337.

[11] M. A. Haidekker, T. Brady, K. Wen, C. Okada, H. Y. Stevens, J. M. Snell, J. A. Frangos, E. A. Theodorakis, Bioorg. Med. Chem. 2002, 10, 3627-3636.

[12] L. M. S. Loura, F. Fernandes, A. C. Fernandes, J. P. P. Ramalho, Biochim. Biophys. Acta 2008, 1778, 491-501.

[13] Y. Wu, F. L. Yeh, F. Mao, E. R. Chapman, Biophys J. 2009, 97, 101-109.

[14] O. A. Kucherak, S. Oncul, Z. Darwich, D. A. Yushchenko, Y. Arntz, P. Didier, Y. Mély, A. S. Klymchenko, J. Am. Chem. Soc. 2010, 132, 4907-4916.

[15] P. J. G. Coutinho, E. M. S. Castanheira, M. C. Rei, M. E. C. D. R. Oliveira, J. Phys. Chem. B 2002, 106, 12841-12846.

[16] G. Hungerford, E. M. S. Castanheira, A. L. F. Baptista, P. J. G. Coutinho, M. E. C. D. R. Oliveira, J. Fluorescence 2005, 15, 835-840.

[17] G. Hungerford, A. L. F. Baptista, P. J. G. Coutinho, E. M. S. Castanheira, M. E. C. D. R. Oliveira, J. Photochem. Photobiol., A 2006, 181, 99-105.

[18] J. P. N. Silva, M. E. C. D. R. Oliveira, P. J. G. Coutinho, J. Photochem. Photobiol., A 2009, 203, 32-39.

[19] E. Bonilla, A. Prelle, J. Histochem. Cytochem. 1987, 35, 619-621.

[20] R. W. Sinkeldam, N. J. Greco, Y. Tor, Chem. Rev. 2010, 110, 2579-2619.

[21] J. Jose, K. Burgess, Tetrahedron 2006, 62, 11021-11037.

[22] E. V. Pozharski, R. C. Macdonald, Anal. Biochem. 2005, 341, 230-400.

[23] V. H. J. Frade, M. S. T. Gonçalves, P. J. G. Coutinho, J. C. V. P. Moura, J. Photochem. Photobiol., A 2007, 185, 220-230.

[24] V. H. J. Frade, S. A. Barros, J. C. V. P. Moura, M. S. T. Gonçalves, Tetrahedron Lett. 2007, 48, 34033407.

[25] V. H. J. Frade, P. J. G. Coutinho, J. C. V. P. Moura, M. S. T. Gonçalves, Tetrahedron 2007, 63, 16541663.

[26] V. H. J. Frade, M. J. Sousa, J. C. V. P. Moura, M. S. T. Gonçalves, Tetrahedron Lett. 2007, 48, 83478352.

[27] V. H. J. Frade, S. A. Barros, J. C. V. P. Moura, P. J. G. Coutinho, M. S. T. Gonçalves, Tetrahedron 2007, 63, 12405-12418. 
[28] C. M. A. Alves, S. Naik, P. J. G. Coutinho, M. S. T. Gonçalves, Tetrahedron Lett. 2009, 50, 44704474.

[29] C. M. A. Alves, S. Naik, P. J. G. Coutinho, M. S. T. Gonçalves, Tetrahedron 2009, 65, 10441-10452.

[30] C. M. A. Alves, S. Naik, P. J. G. Coutinho, M. S. T. Gonçalves, Tetrahedron Lett. 2010, doi :10.1016/j.tetlet.2010.10.165.

[31] M. L. Crossley, R. J. Turner, C. M. Hofmann, P. F. Dreisbach, R. P. J. Parker, Am. Chem. Soc. 1952, 74, $578-584$.

[32] R. Sens, K. H. Drexhage, J. Luminesc. 1981, 24, 709-712. 